Original Article

\title{
Detection of enteroparasites in foliar vegetables commercialized in street- and supermarkets in Aparecida de Goiânia, Goiás, Brazil
}

\author{
Detecção de enteroparasitas em hortaliças comercializadas em feiras e supermercados \\ em Aparecida de Goiânia, Goiás, Brasil
}

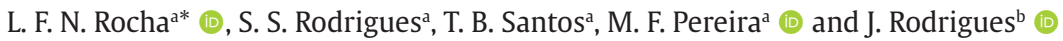 \\ aInstituto Federal de Educação, Ciência e Tecnologia de Goiás - IFG, Aparecida de Goiânia, GO, Brasil \\ bUniversidade Federal de Goiás - UFG, Instituto de Patologia Tropical e Saúde Pública - IPTSP, Goiânia, GO, Brasil
}

\begin{abstract}
Foliar vegetables contaminated with fecal residues are an important route of transmission of intestinal parasites to humans. The aim of this study was to evaluate the presence of parasitic forms of protozoa and helminths on lettuces (Lactuca sativa) and collard greens (Brassica oleracea) sold in street- and supermarkets in the city of Aparecida de Goiânia, Goiás, Brazil. A total of 30 samples of each vegetable ( 15 samples from each supermarkets and street markets) was analyzed. All samples were processed by spontaneous sedimentation method and centrifugal flotation. In $45 \%$ of the samples, immature forms of intestinal parasites were identified with $66.7 \%$ helminths eggs and $33.3 \%$ protozoan cysts or oocysts. Significantly more lettuce samples were contaminated with eggs, cysts or oocyst of at least one parasite than collard green samples $(U=216 ; Z=-3.45 ; P<0.001)$. The parasitic forms were identified morphologically up to the family level with eggs of Ancylostomatidae, Strongyloididae, Ascarididae and Taeniidae, or oocysts of Eimeriidae, to the genus with Cystoisospora sp. and Toxocara sp., and to the species level with Cystoisospora canis, Dipylidium caninum and Hymenolepis nana. The presence of these infective agents in lettuce and collard green from both street- and supermarkets highlights the high risk of spreading parasites by eating raw vegetables sold in Aparecida de Goiânia.
\end{abstract}

Keywords: contamination, lettuce, collard green, helminths, protozoa.

\section{Resumo}

Hortaliças contaminadas com resíduos fecais são importantes vias de transmissão de parasitas intestinais ao homem. O objetivo deste estudo foi avaliar a presença de formas parasitárias de protozoários e helmintos em alface (Lactuca sativa) e couve (Brassica oleracea) vendidas em feiras e supermercados na cidade de Aparecida de Goiânia, Goiás, Brasil. Um total de 30 amostras de cada vegetal (15 amostras de supermercados e 15 de feiras livres) foi analisado. Todas as amostras foram processadas pelos métodos de sedimentação espontânea e centrífugo-flutuação. Em 45\% das amostras foram identificadas formas imaturas de parasitas intestinais sendo $66,7 \%$ ovos de helmintos e $33,3 \%$ de cistos ou oocistos de protozoários. Significativamente, mais amostras de alface estavam contaminadas com ovos, cistos ou oocistos de pelo menos um parasita do que as amostras de couve ( $U=216 ; Z=-3,45 ; P<0,001$ ). As formas parasitárias foram identificadas morfologicamente ao nível de família com ovos de Ancylostomatidae, Strongyloididae, Ascarididae e Taeniidae ou oocistos de Eimeriidae, dos gêneros Cystoisospora sp. e Toxocara sp., e ao nível de espécies com Cystoisospora canis, Dipylidium caninum e Hymenolepis nana. A presença desses agentes infecciosos em alface e couve, provenientes tanto de feiras quanto de supermercados, ressalta o alto risco de veiculação de parasitas pela ingestão de hortaliças cruas comercializadas em Aparecida de Goiânia.

Palavras-chave: contaminação, alface, couve, helmintos, protozoários.

\section{Introduction}

Intestinal parasites are a serious public health problem that globally affect more than a quarter of the human world population (Jourdan et al., 2018; Li et al., 2020). In countries that still have serious social problems, such as Brazil, a high prevalence of enteroparasitoses is common mainly

in regions with lower socioeconomic level (Andrade et al., 2010). This wide occurrence is mainly related to precarious conditions of basic sanitation, inadequate personal hygiene and the lack of care in handling food (Andrade et al., 2010; Fernandes et al., 2015; Rodrigues et al., 2020).

*e-mail: luiz.rocha@ifg.edu.br

Received: November 6, 2020 - Accepted: November 16, 2020 
Foliar vegetables are low-calorie foods with relevant nutritional profiles; they are rich in vitamins, minerals and fibers, essential for the body balance, and, when consumed regularly, they reduce the risk of developing diseases (Wallace et al., 2020). Despite the undeniable nutritional importance, raw or poorly washed vegetables contaminated with fecal residues or irrigated with water contaminated with parasitic forms have been reported as important vehicles for transmission of intestinal parasites to humans (Andrade et al., 2010; Fernandes et al., 2015). In Brazil, contamination of foliar vegetables is one of the main transmission routes of enteroparasites to humans (Soares and Cantos, 2005; Neres et al., 2011), and several studies have confirmed the presence of parasitic forms in vegetables commercialized in all regions of the country (Soares and Cantos, 2005; Esteves and Figueirôa, 2009; Neres et al., 2011; Gomes et al., 2014; Fernandes et al., 2015; Silva et al., 2015; Novacki et al., 2016; Santos et al., 2017; Maldonade et al., 2019; Machado et al., 2020; Rodrigues et al. 2020). However, in the State of Goiás there are still few reports on the occurrence of vegetables contaminated with parasitic forms. Parasitological evaluations of lettuce and collard green were conducted in the city of Anápolis, and in both surveys the contamination with parasitic protozoa and helminths was demonstrated (Neres et al., 2011; Moura et al., 2016). Gomes et al. (2014) also detected enteroparasites in lettuce grown on the edge of the Cascavél river in Goiânia, and Blanco et al. (2019) on lettuce produced and sold in the city of Inhumas. In Aparecida de Goiânia, second city in number of inhabitants of the State with almost 600,000 residents according to IBGE (2019), there is no record of parasitological analysis of foliar vegetables. The evaluation of food contamination has fundamental importance to check the risk of disease transmission, to reflect possible awareness campaigns with the population, to provide health authorities in the municipalities with new information and to encourage the elaboration of public policies of monitoring of vegetable-producing regions.

We report here the occurrence of parasites in Lactuca sativa (lettuce) and Brassica oleracea (collard) commercialized in street markets and supermarkets in the city of Aparecida de Goiânia.

\section{Materials and Methods}

\subsection{Sample collection}

Thirty samples of lettuce and 30 samples of collard acquired between September 2018 and May 2020 were analyzed, with 15 samples of each vegetable coming from street markets and another 15 from supermarkets in the city of Aparecida de Goiânia. One head of lettuce and sheafs of collard were established as the sampling unit, regardless of their weight. The samples were analyzed in the Biology Laboratory of the Federal Institute of Goiás, Aparecida de Goiânia campus or Multiuser Laboratory of IPTSP/UFG.

\subsection{Processing}

The vegetables were processed as described by Esteves and Figueirôa (2009) with some modifications. The samples were defoliated, and damaged leaves and the stalk were discarded. The remaining lettuce and collard leaves were then placed separately into a plastic vessel containing $250 \mathrm{ml}$ of $0.1 \%$ neutral detergent solution and the leaves were washed with a brush. The liquid obtained was filtered through gauze and transferred to a conical glass flask $(300 \mathrm{ml})$. After this procedure, the leaves were transferred, separately, to a clean plastic bag containing another $250 \mathrm{ml}$ of $0.1 \%$ neutral detergent solution and manually and carefully shaken for 5 to 10 minutes. The water resulting from the second washing was also filtered through gauze and transferred to another $300 \mathrm{ml}$ conical glass flask. The liquids were kept at rest for spontaneous sedimentation for 24 hours (Hoffman et al., 1934). Then, the supernatants were discarded, and the sediments from the lettuce or collard washing suspensions joined and transferred to a $50 \mathrm{ml}$ Falcon tube and centrifuged at 2,500 rpm for 2 minutes. After centrifugation, the supernatant was carefully discarded, and the pellet was transferred to a $2 \mathrm{ml}$ microcentrifuge tubes. Two microscope slides from each sample were prepared and stained with Lugol's solution and analyzed using a Leica DM500 optical microscope or Leica DM 750 microscope with integrated ICC50 HD camera at $100 \mathrm{x}$ and $400 \mathrm{x}$ magnification. The rest of the samples was processed by the Zinc Sulphate Centrifugal Flotation Technique (Faust et al., 1939). Two slides from each sample were prepared and analyzed as described above.

\subsection{Statistical analysis}

The results were analyzed with non-parametric MannWhitney U Test using the program Statistica 7.0 (Stat Soft, Tulsa, USA).

\section{Results}

Immature forms of parasites were found in $45 \%$ of the 60 samples (30 lettuces and 30 collard greens). Of this total of positive samples, $40.7 \%$ had bi- or polyparasitism and $59.3 \%$ monoparasitism, regardless of the type of vegetable, commercial establishment or parasitic form evaluated. Forty-two infectious forms were identified in all samples, regardless of the type of vegetable, with $66.7 \%$ helminth eggs and $30.9 \%$ protozoan oocysts and $2.4 \%$ cysts. In addition, $20 \%$ of the lettuces and $6.7 \%$ of the collards were found with unidentified nematode larvae.

Helminths and or protozoa were detected in $70 \%$ of all lettuce samples evaluated. A higher percentual of contaminated samples (73.3\%) was found in lettuce acquired in supermarkets than in samples from street markets (66.7\%), but without statistical difference $(U=92.5$; $\mathrm{Z}=0.87 ; \mathrm{P}=0.41$ ). The most prevalent parasitic form detected in lettuce was Ancylostomatidae / Strongyloididae egg from street markets and supermarkets (Table 1). Eggs of Toxocara sp. and other Ascarididae, Taeniidae and unidentified nematode larvae were also observed in lettuce from both kind of markets. In $26.7 \%$ of the samples from supermarkets Hymenolepis nana eggs were found, and in one of these samples a Dipylidium caninum egg packet was identified (Figure 1; Table 1). Probable trematode eggs were found in two samples and a Trypanoxyuris sp. 
Table 1. Frequency of immature forms of intestinal parasites in lettuce (Lactuca sativa) acquired in 15 street market and supermarket in Aparecida de Goiânia, Goiás.

\begin{tabular}{|c|c|c|c|c|}
\hline \multirow{2}{*}{ Parasites } & \multicolumn{2}{|c|}{ Street Market } & \multicolumn{2}{|c|}{ Supermarket } \\
\hline & $\mathbf{N}^{*}$ & $\%$ & $\mathbf{N}^{*}$ & $\%$ \\
\hline \multicolumn{5}{|l|}{ Helminths (eggs) } \\
\hline Ancylostomatidae/Strongyloides & 4 & 26.7 & 5 & 33.3 \\
\hline Ascarididae & 1 & 6.7 & 4 & 26.7 \\
\hline Hymenolepis nana & - & - & 4 & 26.7 \\
\hline Ovigerous capsule of Dipylidium caninum & - & - & 1 & 6.7 \\
\hline Taeniidae & 1 & 6.7 & 2 & 13.3 \\
\hline Toxocara sp. & 1 & 6.7 & 2 & 13.3 \\
\hline \multicolumn{5}{|l|}{ Protozoa (oocyst) } \\
\hline Cystoisospora canis & 1 & 6.7 & - & - \\
\hline Cystoisospora sp. & 1 & 6.7 & & \\
\hline Coccidian oocyst with multiple sporocysts & 1 & 6.7 & - & - \\
\hline Eimeriidae & 3 & 20 & 1 & 6.7 \\
\hline Cyst unidentified & 1 & 6.7 & - & - \\
\hline
\end{tabular}

${ }^{*}$ Number of positive samples.

Table 2. Frequency of immature forms of intestinal parasites in cabbage (Brassica oleracea) acquired in 15 street market and supermarket in Aparecida de Goiânia, Goiás.

\begin{tabular}{|c|c|c|c|c|}
\hline \multirow{2}{*}{ Parasites } & \multicolumn{2}{|c|}{ Street Market } & \multicolumn{2}{|c|}{ Supermarket } \\
\hline & $\mathbf{N}^{*}$ & $\%$ & $\mathbf{N}^{*}$ & $\%$ \\
\hline \multicolumn{5}{|l|}{ Helminths (eggs) } \\
\hline Ancylostomatidae/Strongyloides & 1 & 6.7 & - & - \\
\hline Toxocara sp. & - & - & 1 & 6.7 \\
\hline \multicolumn{5}{|l|}{ Protozoa (oocyst) } \\
\hline Cystoisospora sp. & 1 & 6.7 & 1 & 6.7 \\
\hline Eimeriidae & 3 & 20 & 1 & 6.7 \\
\hline
\end{tabular}

* Number of positive samples.

egg in one sample from a street market. In only one lettuce sample from a supermarket, a protozoan non-sporulated oocyst of Eimeriidae, was detected. In street markets two samples were found with Eimeriidae oocysts, one with coccidian oocyst containing numerous sporocysts, another non-sporulated Cytoisospora sp. oocyst with morphologically similar to $C$. belli, one unidentified cyst and in one sample, oocysts of Eimeriidae and Cytoisospora canis were detected (Figure 2; Table 1). A higher number of helminths (26 eggs) were identified in lettuce compared to protozoa (seven oocysts and one cyst) with statistical difference $(\mathrm{U}=308 ; \mathrm{Z}=-2.1 ; \mathrm{P}=0.01)$.

Generally, collards had a significantly lower percentage of contaminated samples (20\%) regardless where the vegetables were obtained, than lettuces $(70 \%)(U=216$; $Z=-3.45 ; P<0.001)$. In $13.3 \%$ of the samples from supermarkets and $26.7 \%$ from street markets parasites were identified without effect of the type of commercial establishment on the presence of parasites $(U=98.5 ; Z=0.58$; $\mathrm{P}=0.4$ ). Eggs of Ancylostomatidae / Strongyloididae and Toxocara were recorded in one sample each and in two other samples nematode larvae were detected (Figure 1; Table 2). Oocysts of Cystoisospora sp. resembling to C. belli were found in $6.7 \%$ of the samples from supermarkets and in $13.4 \%$ from street markets. Other Eimeriidae oocysts were found in $6.7 \%$ and $20 \%$ samples from supermarkets and street markets, respectively (Figure 2; Table 2). There was no statistical difference between the number of helminths and protozoa detected in collards $(\mathrm{U}=404 ; \mathrm{Z}=0.68 ; \mathrm{P}=0.5)$.

\section{Discussion}

An elevated number of intestinal parasites was detected in foliar vegetables commercialized in Aparecida de Goiânia, especially lettuce. The index of $70 \%$ positivity of lettuce samples is very high comparing with several others studies carried out in Brazil (Esteves and Figueirôa, 2009; Neres et al., 2011; Fernandes et al., 2015; Silva et al., 2015; Moura et al., 2016; Santos et al., 2017; Machado et al. 2020); the nematode larvae were not included in statistics because they were not identified at the family, genus or species 


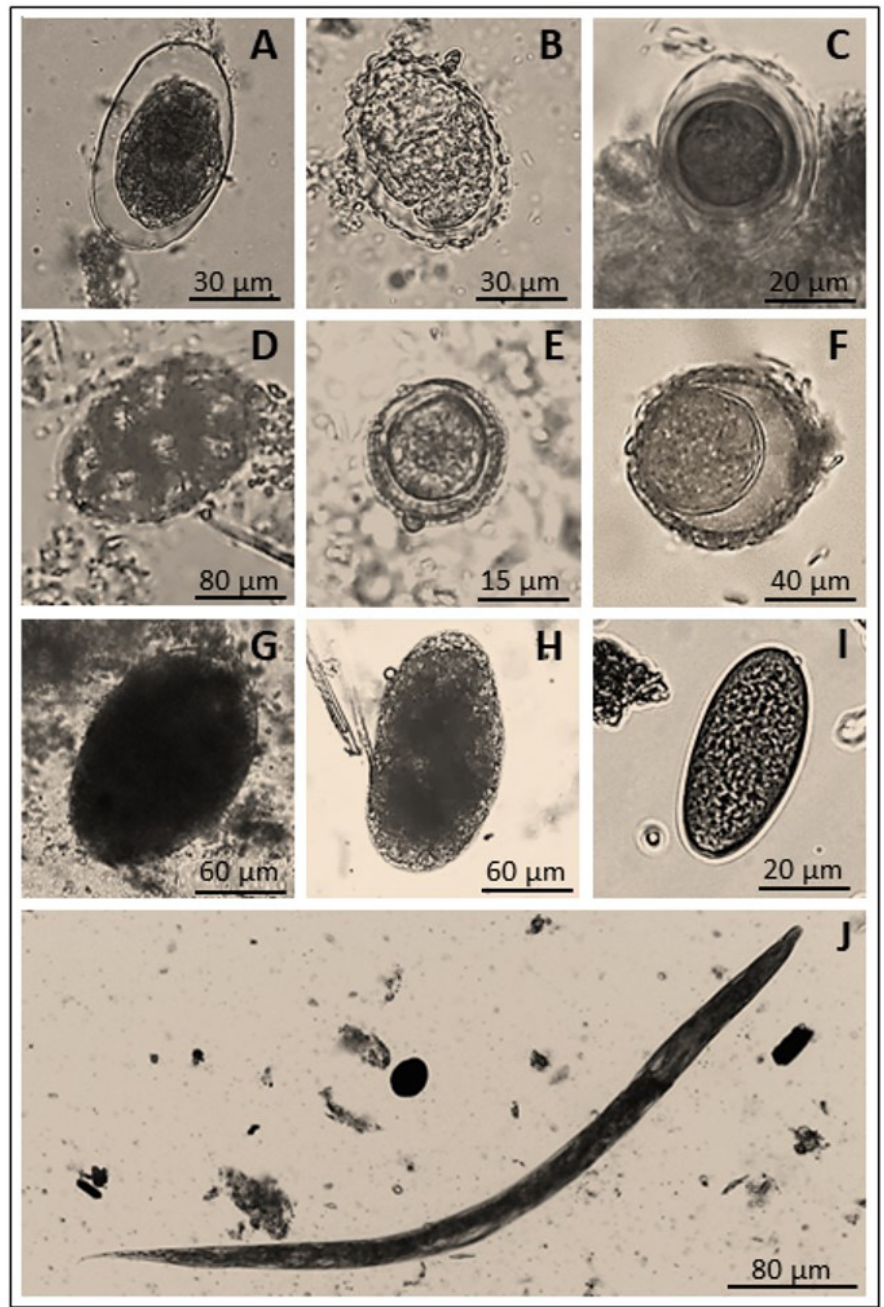

Figure 1. Eggs and larvae of helminths detected in samples of lettuce and collard greens from street market and supermarkets in Aparecida de Goiânia, Goiás. (A) Ancylostomatidae / Strongyloididae; (B) Ascarididae; (C) Hymenolepis nana; (D) ovigerous capsule of Dipylidium caninum; (E) Taeniidae, (F) Toxocara sp.; (G) and (H) probably Trematodae; (I) probably Trypanoxyuris sp.; (J) unidentified nematode larvae.

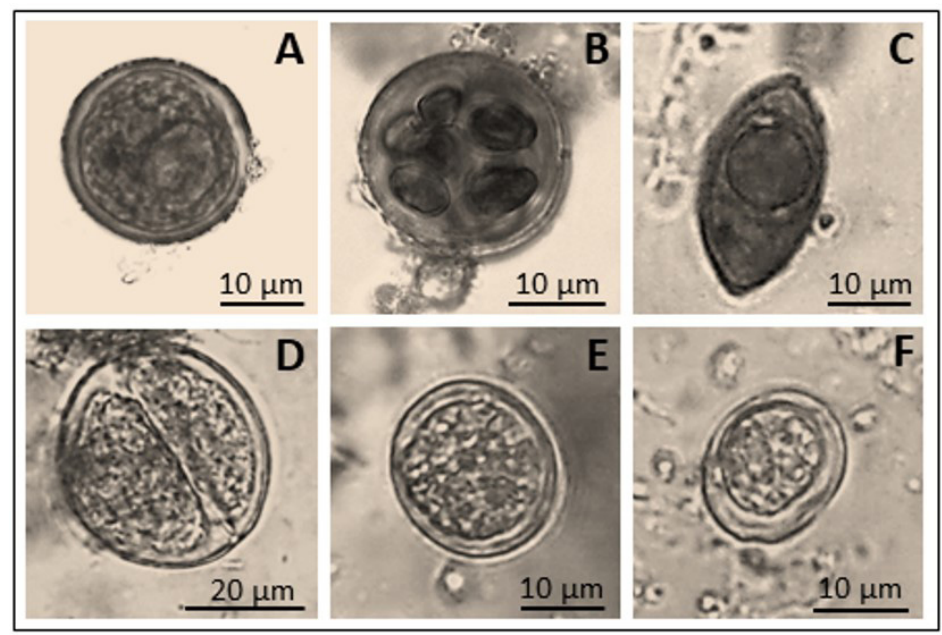

Figure 2. Protozoa detected in samples of lettuce and collard greens from street market and supermarkets in Aparecida de Goiânia, Goiás. (A) Cyst; (B) coccid oocyst with multiple sporocysts; (C) oocyst from Cystoisospora sp. resemble the C. belli; (D) oocyst of C. canis, (E) and (F) oocyst of Eimeriidae. 
level, as they could be larvae of free-living non-parasitic nematodes. In addition, probable trematode eggs and Trypanoxyuris sp. were also not considered in the analysis. This is the highest percentage of lettuce contamination by parasites ever described in the state of Goiás (Neres et al., 2011; Gomes et al., 2014; Moura et al., 2016; Blanco et al., 2019), and similar or higher percentages have been reported in other cities mainly in the north and northeast of Brazil (Furtado et al., 2015; Novacki et al. 2016; Pinto et el., 2018; Carvalho et al., 2019; Oliveira et al., 2020; Rodrigues et al. 2020). The high prevalence in cities of these regions may be related to the lower percentages of basic sanitation, with emphasis on the sewage network, as described by Ministry of Cities in the National Plan for Basic Sanitation of 2019 (Brasil, 2019) and by Dantas et al. (2012). According data recorded in 2018 and published in the National Sanitation Information System (SNIS, 2018), only 10.5\% and $28 \%$ of the population in the north and northeast regions, respectively, have access to a collecting sewage network while the national average in Brazil in this year was $53.2 \%$. This information system also indicated that $23.8 \%$ of the households in Aparecida de Goiânia were connected to the sewage network (SNIS, 2018).

Regarding collard, the percentual of samples contaminated corroborates other studies carried out in the country and even in the State of Goiás (Esteves and Figueirôa, 2009; Moura et al., 2016; Belinelo et al. 2009). The difference in the level de contamination between the two studied vegetables may be related to the morphology of the plants. While lettuce has numerous large, juxtaposed and flexible leaves with a short stalk close to the ground allowing intense contact with the soil, manure, irrigation water and with fecal residues increasing the probability of contamination with parasitic forms during cultivation. $B$. oleracea is an herbaceous vegetable with a longer stalk than lettuce, and leaves are thick and alternating more distant from soil and possible contaminants (Arbos et al. 2010; Rodrigues et al. 2020). In addition, the health conditions of the environment in which vegetables are grown, the cultivation practices used, storage and distribution influence the level of contamination of vegetables (Belinelo et al. 2009; Rodrigues et al. 2020).

The presence of animal parasites such as C. canis, D. caninum, Toxocara sp. and the probable Trypanoxyuris sp. makes us believe that contamination of vegetables often occurs through fecal animal waste. However, the presence of unidentified parasites at the species level that belong to the families Ancylostomatidae, Ascarididae, Eimeriidae, Strongyloididae, Taeniidae, to the genera Cystoisospora and the species $H$. nana suggests that the contamination of lettuce and collard should have also occurred by human feces residues. Due to the similarity between the eggs of helminth species of the Ancylostomatidae family and Strongyloididae, the eggs found in a format resembling these two families were identified as Ancylostomatidae / Strongyloididae. Findings strengthen the high risk of consumers to passively acquire parasitoses as a definitive, intermediate or accidental host when eating raw or undercooked vegetables and / or actively via cutaneous invasion by helminth larvae when handling vegetables. The most common parasites found were nematodes belonging to Ancylostomatidae / Strongyloididae and Ascarididae and by cestodes of the family Taeniidae and $H$. nana. The detection of these parasites is not surprising, considering that the species and families of helminths described above are distributed worldwide and affect animals and humans (Dantas-Torres and Otranto, 2014; Gebrie and Engdaw 2015; Muehlenbachs et al., 2015; Savioli et al. 2017; Jourdan et al., 2018). However, there are still few reports on the occurrence of intestinal parasitosis in humans in Aparecida de Goiânia or on the contamination of food or public places by parasitic forms in this municipality. Damasceno and Costa (2017) reported that among the patients treated in the Hospital das Clínicas - UFG, in the city of Goiânia, patients from Aparecida de Goiânia were the second largest group of people attended with enteroparasitosis, without indicating the type of parasites. Silva et al. (2019) recorded the presence of parasites in fruits commercialized in this city, with emphasis on different species of protozoa and helminth eggs of Ascaris lumbricoides and Fasciola hepatica. In a study on the contamination of squares or parks in this municipality, $36.7 \%$ were contaminated with Toxocara sp. and hookworm eggs, being the first record of potential causative agents of larva migrans in Aparecida de Goiânia (Monteiro et al., 2018). It is interesting to note that in studies on the occurrence of vegetables contaminated with intestinal parasites sold in other cities in the State of Goiás, eggs of A. lumbricoides, H. nana and hookworms were also detected, which shows that these worms are common in the region (Neres et al., 2011; Gomes et al., 2014; Moura et al., 2016; Blanco et al., 2019). In the present study, the identification of most nematodes to the species level was not carried out and, thus, the parasites found could be human parasites or species of animals as the definitive hosts and represent a potential risk to cause anthropozoonoses. In the first case, considering the helminths found, there is a risk of the consumer acquiring ascariasis, hookworm / strongyloidiasis, teniasis, cysticercosis and himenolepiasis. However, as a parasite of animals, it could cause cutaneous larva migrans by larvae of Ancylostoma sp. and Strongyloides sp., visceral larva migrans by ingesting eggs from Toxocara sp. or Ancylostoma sp., hydatidosis also by ingestion of eggs, in this case of Echinococcus granulosus (Taeniidae). In rare cases, pathology due to accidental ingestion of insects containing $D$. caninum cysticercoid larva.

With the exception of one cyst, all protozoa found were coccids, intracellular parasites commonly found in the intestinal tract of a wide range of vertebrate animals, and one of the main causes of serious diseases and economic losses in livestock. Coccid parasites usually have a high specificity for their hosts, and some species affect humans (Chapman et al. 2013). Most of the coccids identified in the present study belonged to the Eimeriidae family and were found mainly in samples from street markets. In this family, the species Cystoisopora belli is a human parasite that has a wide distribution and is found mainly in tropical and subtropical areas (Dubey and Almeria, 2019). Only a few Cytoisospora found had characteristics and size similar to C. belli, which makes us believe that most of the detected eimerids were parasites of animals. The use of manure, the cultivation of vegetables close to breeding areas, the 
free movement of animals at the planting site or the use of water for irrigation that receives animal waste are some of the possibilities of contamination of these vegetables by parasites.

The high number of parasitic structures, especially in lettuce, presupposes a low hygienic care when planting and handling vegetables, putting consumers' health at risk. To our knowledge, this is the first report on the prevalence of enteroparasites in lettuce and collard sold in the city of Aparecida de Goiânia. The presence of parasitic helminths and protozoa highlights the need to strengthen sanitary inspection actions as well as health education campaigns of producers and traders, in order to reduce the contamination of plants by parasites from humans or animals.

\section{Acknowledgements}

The authors thank the Instituto de Patologia Tropical e Saúde Pública (IPTSP) of the Universidade Federal de Goiás (UFG) for assisting in the development of research, the Christian Luz (IPTSP/UFG) for the critical review of the manuscript and the National Council for Scientific and Technological Development - CNPq by the scientific initiation scholarship.

\section{References}

ANDRADE, E.C., LEITE, I.C.G., RODRIGUES, V.O. and CESCA, M.G., 2010. Parasitoses intestinais: uma revisão sobre seus aspectos sociais, epidemiológicos, clínicos e terapêuticos. Revista de APS - Atenção Primária à Saúde, vol. 13, no. 2, pp. 231-240.

ARBOS, K.A., FREITAS, R.J.S., STERTZ, S.C. and CARVALHO, L.A., 2010. Segurança alimentar de hortaliças orgânicas: aspectos sanitários e nutricionais. Food Science and Technology (Campinas), vol. 30, pp. 215-220. http://dx.doi.org/10.1590/ S0101-20612010000500033.

BELINELO, V.J., GOUVÊIA, M.I., COELHO, M.P., ZAMPROGNO, A.C., FIANCO, B.A. and OLIVEIRA, L.G.A., 2009. Enteroparasitas em hortaliças comercializadas na cidade de São Mateus ES, Brasil. Arquivos de Ciências da Saúde da UNIPAR, vol. 13, no. 1, pp. 33-36.

BLANCO, A.J.V., MELO, C.S., SILVA, F.J., GAMA, L.F., FERNANDES, L.B., COSTA, M.O. and MACHADO, S.S. 2019. Ocorrência de parasitas humanos e elementos exógenos em alfaces cultivadas na região de Inhumas, Goiás. In: F.F. Silva, ed. Qualidade de Produtos de Origem Animal 2. Ponta Grossa, PR: Atena Editora, pp. 139-149. http://dx.doi.org/10.22533/at.ed.66619121118.

BRASIL. Ministério do Desenvolvimento Regional. Secretária Nacional de Saneamento Ambiental - SNSA, 2019 [viewed 6 August 2020]. Plano Nacional de Saneamento Básico (PLANSAB): mais saúde com qualidade de vida e cidadania [online]. Brasília: Ministério do Desenvolvimento Regional. Available from: http://www.agersa.ba.gov.br/wp-content/uploads/2019/03/ Versaoatualizada07mar2019_consultapublica.pdf

CARVALHO, A.D., MIRANDA, M.M.A., SILVA, M.A.B., OLIVEIRA, H.M.B.F and FILHO, A.A.O., 2019. Análise parasitológica de amostras de alface (Lactuca sativa) comercializadas em Patos-PB. Revista Uningá, vol. 56, no. 1, pp. 131-139.

CHAPMAN, H.D., BARTA, J.R., BLAKE, D., GRUBER, A., JENKINS, M., SMITH, N.C., SUO, X. and TOMLEY, F.M. 2013. A Selective Review of Advances in Coccidiosis Research. In: D. Rollinson,
M.G. Basánez, S. Brooker, R.B. Gasser, N. Hall, R.C. Oliveira, R.E. Sinden, D.L. Smith, R.C.A. Thompson, X.N. Zhou, ed. Advances in parasitology. London: Academic Press, pp. 93-171.

DAMASCENO, N.S. and COSTA, T.L., 2017. Incidência de enteroparasitoses em pacientes atendidos por um hospital universitário da cidade de Goiânia GO Brasil. Revista Brasileira de Análises Clínicas, vol. 49, pp. 195-199. http://dx.doi. org/10.21877/2448-3877.201600496.

DANTAS, F.A., LEONETI, A.B., OLIVEIRA, S.V.W.B. and OLIVEIRA, M.M.B., 2012. Uma análise da situação do saneamento no Brasil. FACEF Pesquisa: Desenvolvimento e Gestão, vol. 15, no. 3, pp. 272-284.

DANTAS-TORRES, F. and OTRANTO, D., 2014. Dogs, cats, parasites, and humans in Brazil: opening the black box. Parasites $\mathcal{E}$ Vectors, vol. 7, pp. 22. http://dx.doi.org/10.1186/1756-3305-722. PMid:24423244.

DUBEY, J.P. and ALMERIA, S., 2019. Cystoisospora belli infections in humans - the past 100 years. Parasitology, vol. 146, no. 12, pp. 1490-1527. http://dx.doi.org/10.1017/S0031182019000957. PMid:31303182.

ESTEVES, F.A.M. and FIGUEIRÔA, E.O., 2009. Detecção de enteroparasitas em hortaliças comercializadas em feiras livres do Município de Caruaru (PE). Revista Baiana de Saúde Pública, vol. 33, no. 2, pp. 184-193. http://dx.doi.org/10.22278/23182660.2009.v33.n2.a204.

FAUST, E.C., SAWITZ, W., TOBIE, J., ODOM, V., PERES, C. and LINCICOME, D.R., 1939. Comparative efficiency of various technics for the diagnosis of protozoa and helminth in feces. International Journal for Parasitology, vol. 25, no. 3, pp. 241-262. http://dx.doi.org/10.2307/3272508.

FERNANDES, N.S., GUIMARÃES, H.R., AMORIM, A.C.S., REIS, M.B., TRINDADE, R.A. and MELO, A.C.F.L., 2015. Avaliação parasitológica de hortaliças: da horta ao consumidor final. Revista Saúde e Pesquisa, vol. 8, no. 2, pp. 255-265. http://dx.doi. org/10.17765/1983-1870.2015v8n2p255-265.

FURTADO, E.F., LIMA, C.R.C. and BRANDÃO, M.B.S., 2015. Avaliação parasitológica em folhas de alface (Lactuca sativa) comercializadas em Boa Vista-RR. Revista Norte Científico, vol. 10, no. 1, pp. 87-102.

GEBRIE, M. and ENGDAW, T.A., 2015. Review on taeniasis and its zoonotic importance. European Journal of Applied Sciences, vol. 7, no. 4, pp. 182-191. http://dx.doi.org/10.5829/idosi. ejas.2015.7.4.96169.

GOMES, H., JESUS, A.G., MOREIRA, P.F., ALVES, J.B. and NEVES, R.A., 2014. Avaliação parasitológica em alfaces (Lactuca sativa) cultivadas à beira do córrego Cascavel, Goiânia - GO, Brasil. Revista Movimenta, vol. 7, pp. 672-679.

HOFFMAN, W.A., PONS, J.A. and JANER, J.L., 1934. The sedimentationconcentration method in schistosomiasis mansoni. Journal of Public Health, vol. 9, pp. 283-298.

INSTITUTO BRASILEIRO DE GEOGRAFIA E ESTATÍSTICA - IBGE, 2019 [viewed 6 August 2020]. Aparecida de Goiânia [online]. Rio de Janeiro: IBGE. Available from: https://www.ibge.gov.br/ cidades-e-estados/go/aparecida-de-goiania.html

JOURDAN, P.M., LAMBERTON, P.H.L., FENWICK, A. and ADDISS, D.G., 2018. Soil-transmitted helminth infections. Lancet, vol. 391, no. 10117, pp. 252-265. http://dx.doi.org/10.1016/S01406736(17)31930-X. PMid:28882382.

LI, J., WANG, Z., KARIM, M.R. and ZHANG, L., 2020. Detection of human intestinal protozoan parasites in vegetables and fruits: a review. Parasites E Vectors, vol. 13, no. 380, pp. 1-19. http:// dx.doi.org/10.1186/s13071-020-04255-3. PMid:32727529. 
MACHADO, T.C.S., BORGES, C.C.A., MENDONCA, F.C.R. and OLIVEIRA, B.C.E.P.D., 2020. Parasitological evaluation of lettuce served in school meals at a federal state school in Rio de Janeiro, Brazil. Revista de Patologia Tropical, vol. 49, no. 1, pp. 33-44. http:// dx.doi.org/10.5216/rpt.v49i1.61879.

MALDONADE, I.R., GINANI, V.C., RIQUETTE, R.F.R., GURGELGONÇALVES, R., MENDES, V.S. and MACHADO, E.R., 2019. Good manufacturing practices of minimally processed vegetables reduce contamination with pathogenic microorganisms. Revista do Instituto de Medicina Tropical de São Paulo, vol. 61, pp. e14. http://dx.doi.org/10.1590/s1678-9946201961014. PMid:30785568.

MONTEIRO, N.M.C., GONÇALVES, C.A., RODRIGUES, A.A., OLIVEIRA, R.C., LIMA, J.A.S., AVELAR, J.B., CASTRO, A.M. and ALVES REZENDE, H.H., 2018. Ocorrência de potenciais agentes causadores Larva migrans em parques de Praças públicas em Aparecida de Goiânia, Goiás, Brasil. Revista de Biologia Neotropical, vol. 15, no. 2, pp. 73-77. http://dx.doi.org/10.5216/rbn.v15i2.51493.

MOURA, L.R., SANTOS, T. and VIEGAS, A.A., 2016. Avaliação parasitológica em Lactuca sativa (alface) e Brassica oleracea (couve) procedentes da Ceasa no Município de Anápolis-GO. Revista Educação em Saúde, vol. 4, no. 1, pp. 59-66.

MUEHLENBACHS, A., BHATNAGAR, J., AGUDELO, C.A., HIDRON, A., EBERHARD, M.L., MATHISON, B.A., FRACE, M.A., ITO, A., METCALFE, M.G., ROLLIN, D.C., VISVESVARA, G.S., PHAM, C.D., JONES, T.L., GREER, P.W., VÉLEZ HOYOS, A., OLSON, P.D., DIAZGRANADOS, L.R. and ZAKI, S.R., 2015. Malignant Transformation of Hymenolepis nana in a Human Host. The New England Journal of Medicine, vol. 373, no. 19, pp. 1845-1852. http://dx.doi.org/10.1056/NEJMoa1505892. PMid:26535513.

NERES, A.C., NASCIMENTO, A.H., LEMOS, K.R.M., RIBEIRO, E.L., LEITÃO, V.O., PACHECO, J.B.P., DINIZ, D.O., AVERSI-FERREIRA, R.A. and AVERSI-FERREIRA, T.A., 2011. Enteroparasitos em amostras de alface (Lactuca sativa var. crispa), no Município de Anápolis, Goiás, Brasil. Bioscience Journal, vol. 27, no. 2, pp. 336-341.

NOVACKI, J.F., BARCELOS, I.B., VALIATTI, T.B. and GÓIS, R.V., 2016. Análise parasitológica de alfaces (Lactuca sativa) comercializadas em um feirão do município de Ji-Paraná, Rondônia. Revista Uningá Review, vol. 29, pp. 64-69.

OLIVEIRA, É.K.S., GOMES, J.G.F., SILVA-JÚNIOR, H.P., SILVA, A.C., OLIVEIRA, D.K.S. and OLIVEIRA, G.A.L., 2020. Parasitological analysis of vegetables sold in supermarkets and at an open market in Piripiri - Piaui, Brazil. Research, Society and Development, vol. 9, no. 7, pp. e563974462. http://dx.doi. org/10.33448/rsd-v9i7.4462.
RODRIGUES, A.C., DA SILVA, M.D.C., PEREIRA, R.Â.S. and PINTO, L.C., 2020. Prevalence of contamination by intestinal parasites in vegetables (Lactuca sativa L. and Coriandrum sativum L.) sold in markets in Belém, northern Brazil. Journal of the Science of Food and Agriculture, vol. 100, no. 7, pp. 2859-2865. http:// dx.doi.org/10.1002/jsfa.10265. PMid:31953861.

SANTOS, J.S., KUBA, C.A., SANTOS, F.A.G., BATISTA, A.D.S., SITOLINO, S.C.P., PEREIRA, A.C.C., GIUFFRIDA, R. and SANTARÉM, V.A., 2017. Parasitological analysis of green leaf lettuce cultivated in different production systems. Semina: Ciências Agrárias, vol. 38, no. 2, pp. 801-808. http://dx.doi.org/10.5433/16790359.2017v38n2p801.

SAVIOLI, L., GABRIELLI, A.F. and MONTRESOR, A., 2017. Helminthic diseases: intestinal nematode infections. In: S.R. QUAH and W. COCKERHAM, eds. International Encyclopedia of Public Health. Cambridge: Academic Press, pp. 568-575. http://dx.doi. org/10.1016/B978-0-12-801238-3.03106-8.

SILVA, M.R.P., PINHEIRO, F.C., DE PAULA, M.T. and PRIGOL, M., 2015. Avaliação parasitológica de alfaces (Lactuca sativa) comercializadas em um município da Fronteira Oeste, Rio Grande do Sul, Brasil. Revista de Patologia Tropical, vol. 44, no. 2, pp. 163-169. http://dx.doi.org/10.5216/rpt.v44i2.36646.

SILVA, T.A., ÁVILA, A.L.A., ANTONELLI, G., SILVEIRA, M.B., MOREIRA, D.S.M., LIMA, J.A.S., CASTRO, A.M. and REZENDE, H.H.A., 2019. Ocorrência de parasitos em frutas comercializadas nas ruas da cidade de Aparecida de Goiânia, Goiás, Brasil. Multi-Science Journal, vol. 2, no. 2, pp. 68-71. http://dx.doi.org/10.33837/ msj.v2i2.1054.

SISTEMA NACIONAL DE INFORMAÇÕES SOBRE SANEAMENTO SNIS, 2018 [viewed 6 August 2020]. Mapa de indicadores de esgoto [online]. SINIS. Available from: http://appsnis.mdr.gov. br/indicadores/web/agua_esgoto/mapa-esgoto

SOARES, B. and CANTOS, G.A., 2005. Qualidade parasitológica e condições higiênico-sanitárias de hortaliças comercializadas na cidade de Florianópolis, Santa Catarina, Brasil. Revista Brasileira de Epidemiologia, vol. 8, no. 4, pp. 377-384. http:// dx.doi.org/10.1590/S1415-790X2005000400006.

WALLACE, T.C., BAILEY, R.L., BLUMBERG, J.B., BURTON-FREEMAN, B., CHEN, C.O., CROWE-WHITE, K.M., DREWNOWSKI, A., HOOSHMAND, S., JOHNSON, E., LEWIS, R., MURRAY, R., SHAPSES, S.A. and WANG, D.D., 2020. Fruits, vegetables, and health: A comprehensive narrative, umbrella review of the science and recommendations for enhanced public policy to improve intake. Critical Reviews in Food Science and Nutrition, vol. 60, no. 13, pp. 2174-2211. http://dx.doi.org/10.1080/10408398.20 19.1632258. PMid:31267783. 